\title{
ADVANCES IN VITICULTURE, ENOLOGY AND VITIVINICULTURAL ECONOMY: CIÊNCIA E TÉCNICA VITIVINÍCOLA 2020
}

\author{
AVANÇOS EM VITICULTURA, ENOLOGIA E ECONOMIA VITIVINÍCOLA: CIÊNCIA E TÉCNICA \\ VITIVINÍCOLA 2020
}

Sara Canas, Jorge Cunha, José Eduardo Eiras-Dias

Instituto Nacional de Investigação Agrária e Veterinária, Pólo de Dois Portos/Estação Vitivinícola Nacional, Quinta de Almoinha, 2565-191

Dois Portos, Portugal.

\section{SUMMARY}

Research insights arising from the sciences of Viticulture, Enology and Vitivinicultural Economy are crucial for responding to an everincreasing set of challenges - such as climate change, environmental issues and a global and more competitive market - faced by the players in the vitivinicultural sector. In this context, the scientific journals play a key role in spreading the knowledge acquired worldwide and contributing to the generation of new ideas and new research lines. The Ciência e Técnica Vitivinícola is one of the oldest and few scientific journals specifically devoted to these three branches of science. In 2020, twelve articles from several international research teams were published, covering a wide range of current topics, including: sustainability of viticulture and winemaking; modelling of climate impact on wine production; control of pests and diseases; management and adaptability of grapevine varieties; quality and differentiation of wine based on minority grapevine varieties, native yeasts from grapevine and winemaking technologies; wine authenticity and traceability; botrytized wines; human resource management in small wine companies.

\section{RESUMO}

Os conhecimentos decorrentes das ciências da Viticultura, Enologia e Economia Vitivinícola são cruciais para responder a um conjunto crescente de desafios - como as alterações climáticas, as questões ambientais e a existência de um mercado global e mais competitivo enfrentado pelos agentes do sector vitivinícola. Neste contexto, as revistas científicas desempenham um papel chave na medida em que asseguram a difusão do conhecimento adquirido mundialmente e contribuem para a geração de novas ideias e de novas linhas de investigação. A Ciência e Técnica Vitivinícola é uma das poucas, e das mais antigas, revistas científicas especificamente dedicadas aos três ramos da ciência acima mencionados. Em 2020, publicou doze artigos de várias equipas de investigação internacionais, cobrindo uma vasta gama de assuntos de grande atualidade, designadamente: sustentabilidade da viticultura e da produção de vinho; modelização do impacto do clima na produção de vinho; controlo de pragas e doenças; gestão e adaptabilidade de variedades de videira; qualidade e diferenciação do vinho com base em castas minoritárias, leveduras nativas da videira e tecnologias de vinificação; autenticidade e rastreabilidade do vinho; vinhos botritizados; gestão de recursos humanos em empresas vinícolas de pequena dimensão.

Keywords: Viticulture, enology, vitivinicultural economy.

Palavras-chave: Viticultura, enologia, economia vitivinícola.

Vineyard cultivation and winemaking are ancestral practices (Pagnoux et al., 2021) of remarkable socio-economic importance worldwide. According to the OIV data, the total surface area planted with vines is estimated at 7.4 million ha, encompassing Europe, North America, South America, South Africa, Australia, New Zealand and East Asia; the corresponding wine production is estimated at 260 million hL (OIV, 2020).
The results of these activities have evolved over time based on the advancement of knowledge arising from the underlying sciences - Viticulture and Enology - which has been closely related to the progress of technology. Over the last decades, significant advances in technology aimed at viticultural practices and oenological processes, as well as in the instrumentation supporting analytical methodologies and tools for data analysis are evident. 
In the face of climate change, environmental issues and a global and more competitive market, current challenges of Viticulture and Enology include: sustainability/circular economy; adaptability of grapevine varieties; control of pests and diseases; authenticity and food safety of vine-derived products; quality, differentiation and innovation of vine-derived products; health effects of vinederived products. In this context, the science of Vitivinicultural Economy is mainly focused on economic and social aspects of production, consumption and trade.

Some of these topics were recently addressed in the twelve articles published by the Ciência e Técnica Vitivinícola over 2020.

Sustainability of viticulture and winemaking was the core of a review article (Costa et al., 2020), highlighting the importance of water use and wastewater management in Mediterranean regions, such as southern Portugal, particularly affected by the climate change, and describing possible strategies to improve them in the vineyard and winery.

An innovative methodology to modelling the impact of climate on the wine production temporal cycles was reported by Cunha and Richter (2020); the article also shows its applicability for a period of about 80 years in two world-renowned but considerably different wine-producing regions: Douro and Vinhos Verdes. This new tool can be of great significance for planning purposes as well as for mitigation strategies facing the scenarios that combine technological progress and climate change.

An approach to the efficient management of 'Sauvignon Blanc' variety in a high-altitude region was explored by Macron et al. (2020) based on two training systems - Y-trellis and vertical shoot position trellis. Y-trellis was pointed out as the best solution to balance vegetative growth and production, providing increased productivity without compromising grape composition.

Regarding the control of pests and diseases, Figueiredo et al. (2020) studied the role of one subtilase (a constitutive serine protease) in grapevine response to Erysiphe necator and Botrytis cinerea infection, which cause two devastating diseases, powdery mildew and gray mold, respectively. No significant up-regulation of gene expression was observed in both cases, suggesting a host-pathogen specificity for this subtilase. This technical note open doors for further research towards the development of new grapevine varieties with high degree of tolerance to these pathogens through breeding programs, which is of utmost importance to reduce the use of fungicides.
Within the same scope, another article (Ocete et al., 2020) presented a detailed analysis of the spread of Xylotrechus arvicola, a pest with increasing expression in Spain, through a long-term study made in La Rioja region. A new methodology to estimate the infestation pressure over time was proposed, which may allow improving the management of this pest.

The adaptability of grapevine was addressed in one article (Loureiro et al., 2020) focused on the assessment of rootstocks for a specific variety, 'Verdejo Negro', based on agronomic and oenological requirements. The relevance of this study lies in the central role played by minority grapevine varieties in terms of biodiversity, identity of wine-producing regions, and new styles of wine they can give rise to.

In line with the previous one, the article of Piras et al. (2020) unveiled the volatile and sensory profiles of white wines produced from three Portuguese minority grapevine varieties, 'Malvasia' (Colares), 'Verdelho' and 'Galego Dourado'. Differentiation of wines according to the grapevine variety and to the vintage was emphasized.

Botrytized wines, also known as noble rot wines, which stand out for their peculiar features, were extensively covered in a review article (Kallitsounakis and Catarino, 2020). A comprehensive and critical perspective, including all stages and factors involved in their production, as well as the underlying microbiological, chemical and sensory aspects, was provided. Implications of climate change and market trends in this field were also addressed.

Concerning the quality and differentiation of wine, one article (Pozzatti et al., 2020) was devoted to the effect of winemaking technology on the volatile composition and sensory profile of 'Marselan' wine, which is of increasing interest in new world wine countries. Thermovinification, integrale vinification, classic winemaking, and classic winemaking combined with ultrasound were examined through chemometric analysis, revealing themselves as possible alternatives for obtaining wines with different aromatic profiles.

Microorganisms, such as yeasts and bacteria, are indisputably important in the winemaking process, shaping the wine quality. The article of BarragánCastillo et al. (2020) reported innovative information on native yeasts collected from distinct organs of grapevines established in Queretaro (Mexico), showing that the yeast populations varied according to the organ and the sampling season, but all isolates corresponded to non-Saccharomyces yeasts. Besides, the oenological potential of Pichia cf. kluyveri $3.1 \mathrm{HM}$ was proven, which can be an asset to enhance the regional character of the wine. 
Ensuring the uniqueness and quality of each wine to protect the producer, the producing region, and the consumer from fraud is a complex task and, therefore, requires extensive research. This topic was developed by Zava et al. (2020) in a review article on wine authenticity and traceability. Special attention was dedicated to the isotopic composition as well as to the wine chemical composition and the main sources of variability (grapevine variety, geographical origin and vintage), highlighting metabolomics (including data from proton nuclear magnetic resonance spectroscopy) and chemometrics as promising approaches to this purpose.

Ferrer et al. (2020) investigated how the level of human resource management practices (recruitment and selection; training and development; remuneration) evolve with the size and age of small wine companies and their relationship with the business performance. This article provides a relevant insight into the social strand of small family businesses in the vitivinicultural sector, which still have considerable weight in several wine-producing countries.

\section{ACKNOWLEDGEMENTS}

The Editorial Board thank all authors and reviewers for their commitment and excellent contribution to a comprehensive and topical set of research works published by the Ciência e Técnica Vitivinícola over 2020. The Editorial Board also acknowledges EDP Sciences for the technical support, and sponsors for the financial support.

\section{REFERENCES}

Barragán-Castillo Y.M., Miranda-Castilleja D.E., Aldrete-Tapia J.A., Arvizu-Medrano S.M., Martínez-Peniche R.Á., 2020. Native yeast from distinct organs of grapevines established in Queretaro, Mexico, and their potential oenological utilization. Ciência Téc. Vitiv., 35, 30-41.

Costa J.M., Oliveira M., Egipto R.J., Cid J.F., Fragoso R.A., Lopes C.M., Duarte E.N., 2020. Water and wastewater management for sustainable viticulture and oenology in South Portugal - a review. Ciência Téc. Vitiv., 35, 1-15.
Cunha M., Richter C., 2020. Climate-induced cyclical properties of regional wine production using a time-frequency approach in Douro and Minho Wine Regions. Ciência Téc. Vitiv., 35, 16-29.

Ferrer J.R., Abella-Garcés S., Maza-Rubio M.T., 2020. Human resource practices and performance in small Spanish wineries, and their evolution with age and size. Ciência Téc. Vitiv., 35, 107-119.

Figueiredo J., Cunha J., Eiras-Dias J., Silva M.S., Figueiredo A., 2020. Pathogen-related specificity of subtilase VVISBT4.19 X1 in the Vitis vinifera defence response. Ciência Téc. Vitiv., 35, 4248 .

Kallitsounakis G., Catarino S., 2020. An overview on botrytized wines. Ciência Téc. Vitiv., 35, 76-106.

Loureiro M.D., Moreno-Sanz P., Suárez B., 2020. Evaluation of rootstocks for the 'Verdejo Negro' cultivar. Ciência Téc. Vitiv., 35, 120-132.

Marcon J.L., Wurz D.A., Brighenti A.F., Allebrandt R., Pereira de Bem B., Rufato L., 2020. Agronomic performance of 'Sauvignon Blanc' variety trained in y-trellis and vertical shoot position trellis in a high-altitude region of southern Brazil. Ciência Téc. Vitiv., 35, 167-175.

Ocete R., Armendáriz I., Ocete C.A., Maistrello L., Valle J.M., Rodríguez A., Usategui L., 2020. Spread parameters of the borer Xylotrechus Arvicola (Olivier) (Coleoptera: Cerambycidae) in a 'Tempranillo' vineyard in La Rioja (Spain): A long-term study. Ciência Téc. Vitiv., 35, 148-166.

OIV, 2020. State of the world vitivinicultural sector in 2019. 15 p. International Organisation of Vine and Wine, Paris.

Pagnoux C., Bouby L., Valamoti S.M., Bonhomme V., Ivorra S., Gkatzogia E., Karathanou A., Kotsachristou D., Kroll H., Terral J.-F., 2021. Local domestication or diffusion? Insights into viticulture in Greece from Neolithic to Archaic times, using geometric morphometric analyses of archaeological grape seeds. J. Archaeol. Sci., 125, 105263 ,

Piras S., Brazão J., Ricardo-da-Silva J.M., Anjos O., Caldeira I., 2020. Volatile and sensory characterization of white wines from three minority Portuguese grapevine varieties. Ciência Téc. Vitiv., 35, 49-62.

Pozzatti M., Guerra C.C., Martins G., Santos I., Wagner R., Ferrão M.F., Manfroi V., 2020. Effects of winemaking on 'Marselan' red wines: volatile compounds and sensory aspects. Ciência Téc. Vitiv., 35, 63-75.

Zava A., Sebastião P.J., Catarino S., 2020. Wine traceability and authenticity: approaches for geographical origin, variety and vintage assessment. Ciência Téc. Vitiv., 35, 133-147. 